\title{
Licensing Challenges Associated with Autonomous Control
}

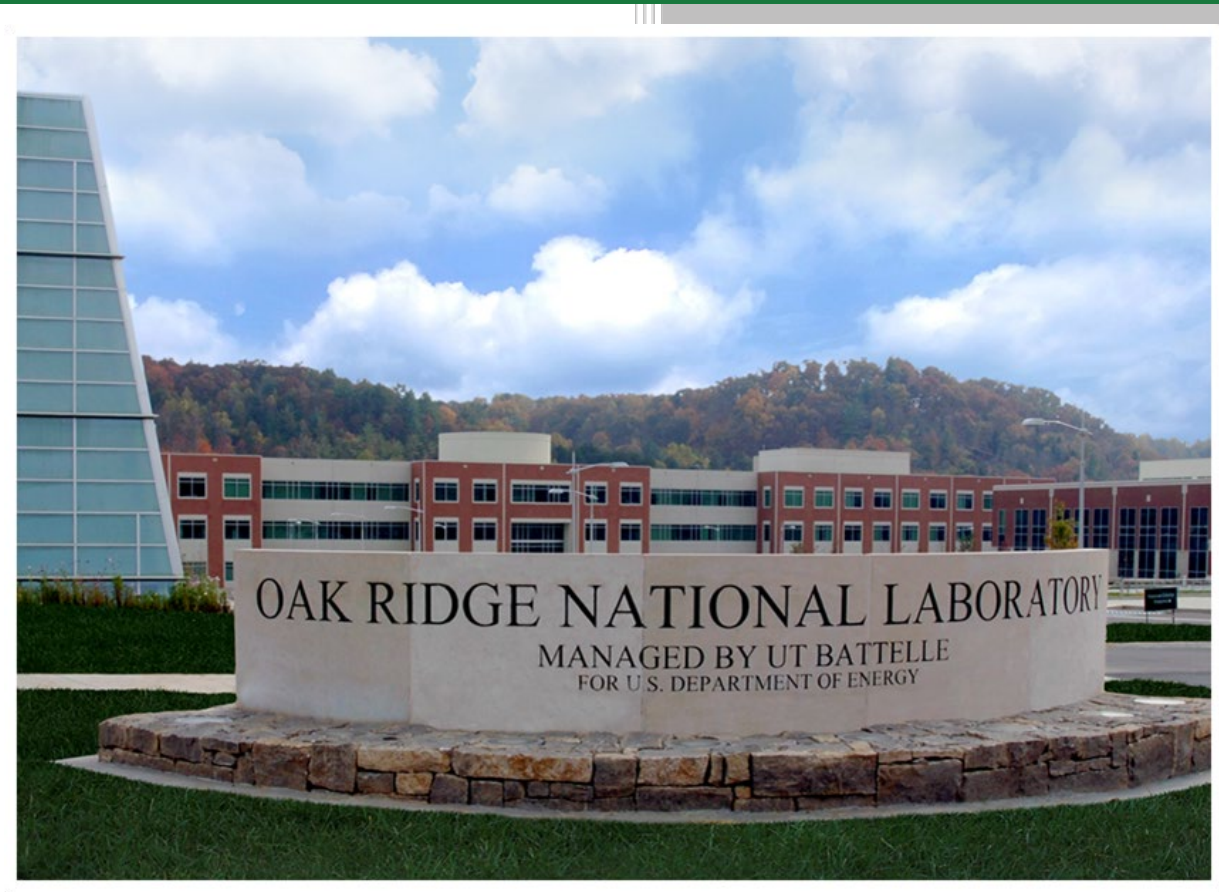
R. J. Belles
M. D. Muhlheim

Approved for public release. Distribution is unlimited.

December 2018 
This report was prepared as an account of work sponsored by an agency of the United States Government. Neither the United States Government nor any agency thereof, nor any of their employees, makes any warranty, express or implied, or assumes any legal liability or responsibility for the accuracy, completeness, or usefulness of any information, apparatus, product, or process disclosed, or represents that its use would not infringe privately owned rights. Reference herein to any specific commercial product, process, or service by trade name, trademark, manufacturer, or otherwise, does not necessarily constitute or imply its endorsement, recommendation, or favoring by the United States Government or any agency thereof. The views and opinions of authors expressed herein do not necessarily state or reflect those of the United States Government or any agency thereof.

DOCUMENT AVAILABILITY

Reports produced after January 1, 1996, are generally available free via US Department of Energy (DOE) SciTech Connect.

Website http://www.osti.gov/scitech/

Reports produced before January 1, 1996, may be purchased by members of the public from the following source:

National Technical Information Service

5285 Port Royal Road

Springfield, VA 22161

Telephone 703-605-6000 (1-800-553-6847)

TDD 703-487-4639

Fax 703-605-6900

E-mail info@ntis.gov

Website http://www.ntis.gov/help/ordermethods.aspx

Reports are available to DOE employees, DOE contractors, Energy Technology Data Exchange representatives, and International Nuclear Information System representatives from the following source:

Office of Scientific and Technical Information

PO Box 62

Oak Ridge, TN 37831

Telephone 865-576-8401

Fax 865-576-5728

E-mail reports@osti.gov

Website http://www.osti.gov/contact.html 
Reactor and Nuclear Systems Division

\title{
LICENSING CHALLENGES ASSOCIATED WITH AUTONOMOUS CONTROL
}

\author{
R. J. Belles \\ M. D. Muhlheim
}

Date: December 2018

Prepared by

OAK RIDGE NATIONAL LABORATORY

Oak Ridge, TN 37831-6283

managed by

UT-BATTELLE, LLC

for the

US DEPARTMENT OF ENERGY

under contract DE-AC05-00OR22725 



\section{CONTENTS}

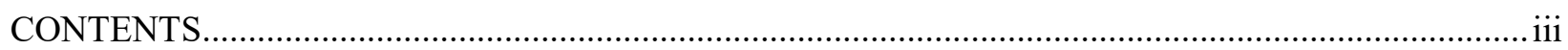

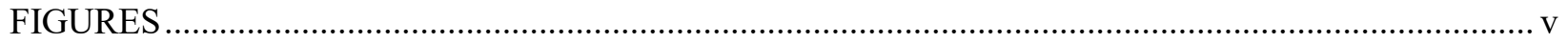

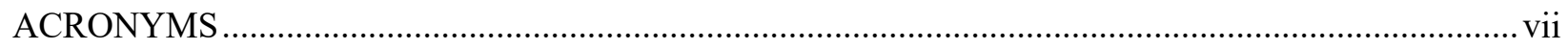

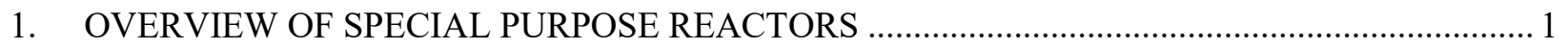

1.1 H.R. 5515 - National Defense Authorization Act for FY2019 ............................................ 1

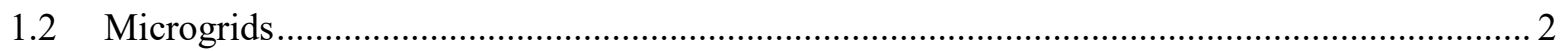

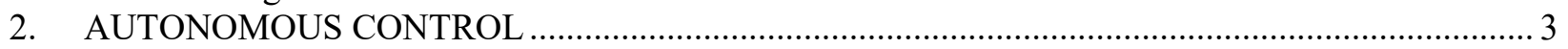

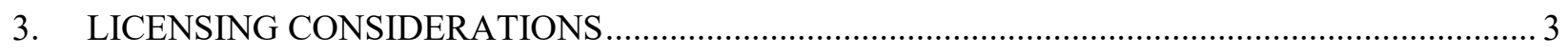

3.1 Nuclear Regulatory Commission as the Regulatory Authority ............................................ 4

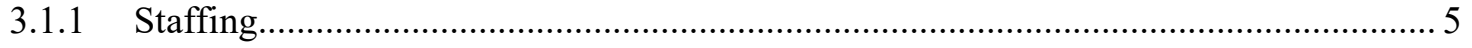

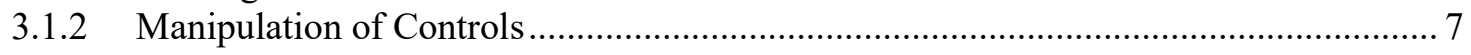

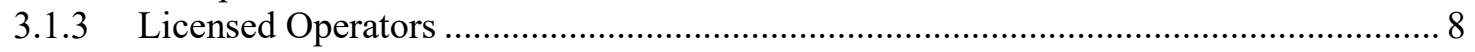

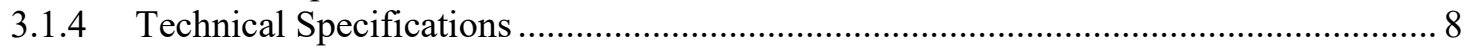

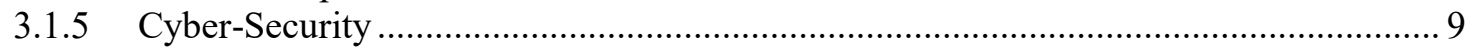

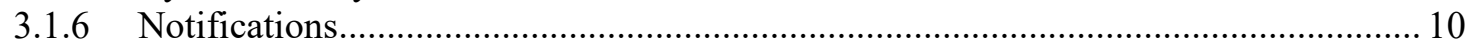

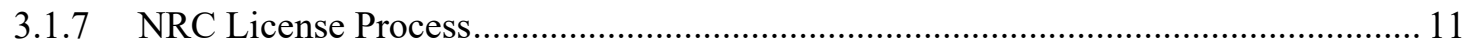

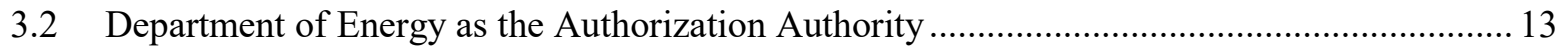

3.3 Department of Defense as the Authorization Authority …..................................................... 14

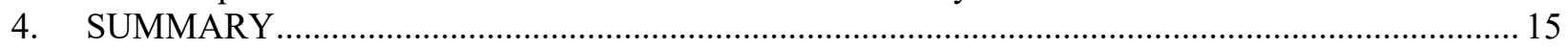

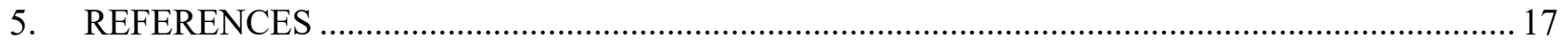





\section{FIGURES}

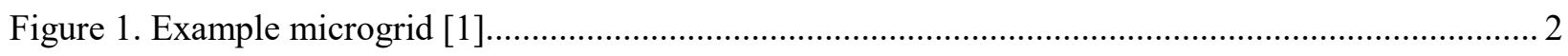

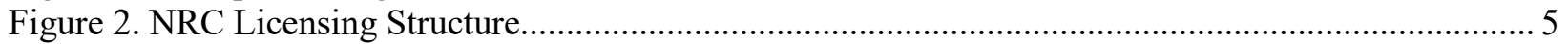

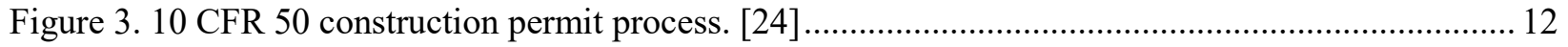

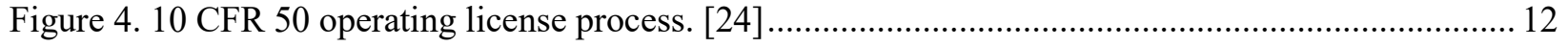

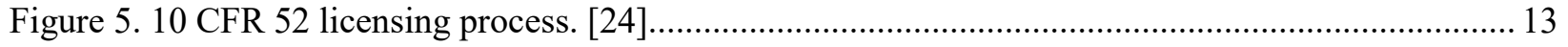

Figure 6. Navy submarines reflect remotely operating DoD reactors [27] ........................................... 14 



\section{ACRONYMS}

$\begin{array}{ll}\text { ACRS } & \text { Advisory Committee on Reactor Safeguards } \\ \text { AEA } & \text { Atomic Energy Act } \\ \text { CFR } & \text { Code of Federal Regulations } \\ \text { COL } & \text { combined license } \\ \text { CP } & \text { construction permit } \\ \text { DOE } & \text { US Department of Energy } \\ \text { DoD } & \text { US Department of Defense } \\ \text { EIS } & \text { environmental impact statement } \\ \text { FSAR } & \text { final safety analysis report } \\ \text { ITAAC } & \text { inspections, tests, analyses, and acceptance criteria } \\ \text { LCO } & \text { limiting conditions for operation } \\ \text { LWA } & \text { limited work authorization } \\ \text { LWR } & \text { light water reactor } \\ \text { NEI } & \text { Nuclear Energy Institute } \\ \text { Non-LWR } & \text { non-light water reactor } \\ \text { NRC } & \text { US Nuclear Regulatory Commission } \\ \text { OP } & \text { operating permit } \\ \text { PSAR } & \text { preliminary safety analysis report } \\ \text { RG } & \text { regulatory guide } \\ \text { SMR } & \text { small modular reactor } \\ \text { SNM } & \text { special nuclear material } \\ \text { SPR } & \text { special purpose reactor } \\ \text { TS } & \text { technical specification } \\ \text { USC } & \text { United States Code } \\ \end{array}$





\section{OVERVIEW OF SPECIAL PURPOSE REACTORS}

Very small special purpose reactors (SPRs), or microreactors at less than $50 \mathrm{MW}$ electric, are under consideration by various entities for applications in remote installations and communities. These entities include remote municipalities, the US Department of Defense (DoD), and the US Department of Energy (DOE). SPRs or microreactors may be transportable from a factory with fresh fuel included to serve as a complete power battery. This type of plug-and-go resource requires inherently positive safety attributes and robust design. SPRs and microreactors are being designed to fulfill black-start or microgrid capabilities and to provide protection against severe natural phenomena or cyber security threats. These reactors would be available to operate for several years without a need to shut down for refueling.

Modifications to regulatory requirements could allow for small, passively safe reactors to be operated remotely by an offsite operations crew. Intelligent control and diagnostic tools may provide an opportunity for autonomous operation of these types of power plants. Beyond siting at remote US locations, these reactor attributes could allow for consideration of siting a microreactor at a DoD forward operating base. Ultimately, in such a case, an SPR may even need to be transportable on short notice to another location after its initial use. In any remote application, SPRs could significantly reduce costly fossil fuel deliveries and extreme weather fuel conditioning.

The necessity of a reliable electrical power supply to support critical national security infrastructure needs is increasingly apparent to combat cyberattacks and rogue terrorist attacks, which have become frequent events on the world stage. As discussed in Section 1.1, such considerations recently led Congress to provide bipartisan support to investigate microreactors as an option for reliable electrical power to critical national security infrastructure.

Because autonomous reactor control may be an important aspect of remotely installed microreactors, some consideration must be given to safety and licensing. This paper investigates some of the US licensing considerations for autonomously controlled reactors. This report meets a Level 3 milestone for the SPR project.

\subsection{H.R. 5515 - NATIONAL DEFENSE AUTHORIZATION ACT FOR FY2019}

Section 327 of House Rule 5515 requires DOE to provide a report by August 2019 on microreactors $(\leq 50 \mathrm{MWe})$ :

describing the requirements for, and components of, a pilot program to provide resilience for critical national security infrastructure at Department of Defense facilities with high energy intensity and currently expensive utility rates and Department of Energy facilities by contracting with a commercial entity to site, construct, and operate at least one licensed micro-reactor at a facility identified under the report by December 31, 2027.

The expectation under the bill is that the microreactor will be licensed and regulated by the US Nuclear Regulatory Commission (NRC). However, any existing authority of DOE and DoD to permit the siting, construction, and operation of a microreactor should also be examined. The following points should be addressed in the evaluation:

- assessments of different nuclear technologies to provide energy resiliency for critical national security infrastructure;

- a survey of potential commercial stakeholders with whom to enter into a contract under the pilot program to construct and operate a licensed microreactor; 
- options to enter long-term contracting, including various financial mechanisms for such purpose;

- identification of requirements for microreactors to provide energy resilience to mission-critical functions at identified critical national security infrastructure facilities;

- an estimate of the costs of the pilot program;

- a timeline with milestones for the pilot program; and

- recommendations for any legislative changes necessary for $\mathrm{DOE}$ and $\mathrm{DoD}$ to permit siting, construction, and operation of a microreactor.

\subsection{MICROGRIDS}

One method to provide energy resilience to mission-critical functions is to use a microreactor as a generating source on a microgrid. DOE defines a microgrid as a local energy grid with control capability [1]. The local grid would normally be powered through a connection with the traditional grid, as shown at the top of Figure 1, across a distribution substation. In the event of an upset on the traditional grid, the microgrid disconnects from the traditional grid and operates autonomously. This requires that a fast-transfer or fast-start power source be available to the microgrid and possibly downstream from load shedding.

SPRs and microreactors are typically designed with the capability to operate in island mode, meaning that an SPR can disconnect from the traditional grid (loss of load), provide for its own house loads (island mode) without a reactor trip, and then operate to power the isolated microgrid. A microgrid backed by an SPR is an option for critical DoD or DOE facilities, as well as some remote facilities. The microgrid can be a subset of the local grid so that only priority loads are energized in an emergency, as for a single customer or a partial feeder microgrid, as shown in Figure 1. Alternately, the microgrid can power all loads for an entire facility (i.e., a full feeder or full substation microgrid as shown in Figure 1).

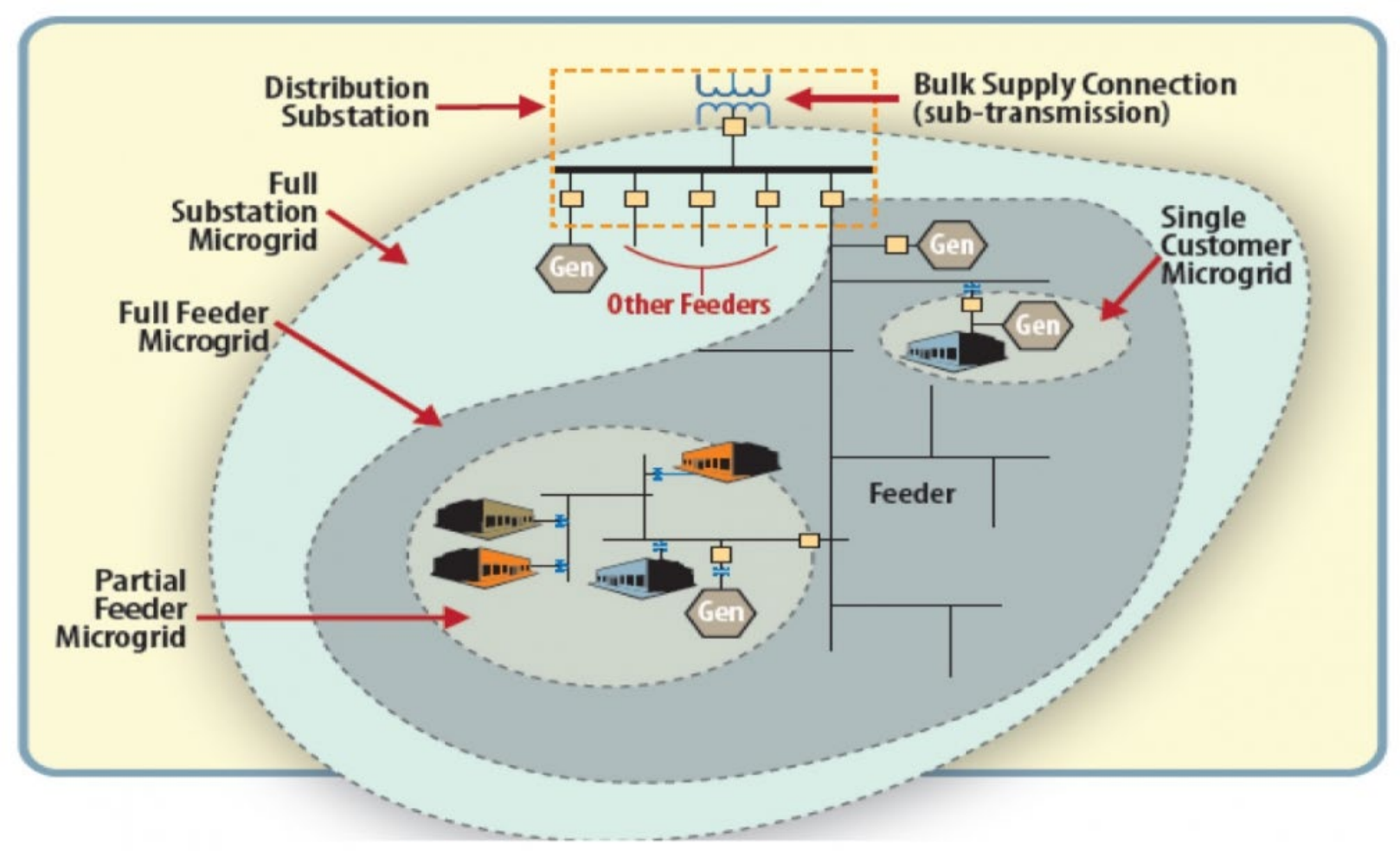

Figure 1. Example microgrid [1]. 


\section{AUTONOMOUS CONTROL}

Economic advantages are being sought for many advanced reactor concepts as compared to larger lightwater reactors (LWRs). Higher levels of automation and autonomous controls are part of the economic discussion for SPRs and microreactors. Higher levels of automation and fault tolerance are expected to increase availability, reduce accident risk, and lower operating costs [2]. Automated control implies a self-acting reactor response based on fixed setpoints, while autonomous control implies the capability of a reactor to take independent action based on consideration of multiple inputs and trends [3]. Automated control based on fixed setpoints is a basic form of autonomous control with follow-up operator actions expected. However, more complex autonomous reactor control systems have the potential for operating with very high levels of performance and reliability with little or no human assistance required to adjust power level, move control elements, start or stop pumps, open or close valves, etc. in response to plant operations, transients, or casualties. This approach could lead to reactor designs with an offsite control room. Fully autonomous controls are necessary when human interaction is not possible or severely time constrained such as in space reactor applications. Near-autonomous controls are necessary when the operating and maintenance staff is not onsite due to the reactor's remote location. Still, personnel can be dispatched to the site as necessary. To be autonomous, a control system should provide adequate control actions in the presence of significant uncertainties. The key attributes of highly autonomous control systems are (1) effective performance under all process operating conditions and performance demands and (2) the ability to compensate for system failure without external intervention [4].

Control systems with varying levels of autonomy have been employed in robotic, transportation, spacecraft, and manufacturing applications [5-8]. Automatic control system responses assist the operator in maintaining a nuclear plant within the required technical specification (TS) limits. However, high levels of autonomous control have not been implemented for an operating nuclear power plant. A system with full autonomous control may enable remote operation of a microreactor using the plant's supervisory control system. In current LWRs, the supervisory control system acts as an extension of the human operator to ensure safe, reliable operation of the plant. The supervisory control system provides the framework for integrating algorithm-based controllers and diagnostics at the subsystem level, with command and decision modules at higher levels. The higher levels of the functional hierarchy are where the supervisory control system provides autonomous capabilities while accommodating the human operator's analytical approach and need to be cognizant of the state of the plant [2]. Fully autonomous systems must be able to consider plant startup, normal plant operations, shutdown, decay heat removal, emergency operations, load-following, alarm response, and anticipatory maintenance — all while adapting to disturbances, degradation, equipment faults, and other upsets.

The supervisory controller must communicate information to the operator about the status of the plant, any data needed to support the information, any impending control action, the reasons for the control action, and the expected result(s) of the action. Near autonomous control can extend the time period before human operator interaction is necessary for safe operation of the plant. Fully autonomous control would theoretically eliminate the need for an operator altogether. However, it is expected that a human operator can interact and direct the goals and actions of the supervisory controller for any type of autonomous control system. In addition, an informational interface to the maintenance staff can supply component and device health status information to enable optimized, just-in-time maintenance scheduling $[2]$.

\section{LICENSING CONSIDERATIONS}

Between 1954 and 1977, the US Army investigated the use of land-based nuclear power plants to support remote military needs. During this time, the Army operated 8 small special-purpose reactors, of which 2 
of were considered mobile and 3 were considered portable. The mobile reactors included a pallet-based gas-cooled reactor (designated ML-1) that was transportable by aircraft and a barge-based pressurized water reactor (designated MH-1A) that was moored in the Panama Canal for nine years. Three portable pressurized water reactors were built in parts and shipped to remote bases (Greenland, Wyoming, and Antarctica) to supply power to military installations. None of these reactors were subject to licensing by the US Atomic Energy Commission. Eventually, the Army cancelled the program because the development of complex, compact nuclear plants was expensive and time consuming [9].

The US Navy operates nuclear-powered ships today with design and surface prototype efforts dating back to 1947. The Naval Nuclear Propulsion Program represents a successful example of a DoD organization that is responsible for military reactors that are exempt from NRC licensing. Other DoD reactor facilities are possible under Section 91 of the Atomic Energy Act (AEA) [10].

Otherwise, the NRC licenses all commercially owned nuclear power plants that produce electricity or provide other energy services in the United States, no matter where they may be sited. ${ }^{1}$ After the initial license is granted, it may be amended, renewed, transferred, or otherwise modified, depending on activities that affect the reactor during its operating life. The NRC also licenses research and test reactors for research, testing, and training applications, although DOE also has this authority for research and test reactors operating at DOE facilities.

\subsection{NUCLEAR REGULATORY COMMISSION AS THE REGULATORY AUTHORITY}

The Nuclear Energy Institute (NEI) recently completed a preliminary roadmap for the deployment of microreactors at DoD facilities. The NEI roadmap assumes that the NRC will license and regulate any domestic microreactor installation, including those at stateside DoD facilities [11]. The NRC licensing structure is shown in Figure 2.

As noted in Part 50, Section 22 of Title 10 of the Code of Federal Regulations (10 CFR 50.22), Licenses for Commercial and Industrial Facilities, per the AEA, an NRC class 103 reactor license will be issued to "an applicant qualified to transfer or receive in interstate commerce, manufacture, produce, transfer, acquire, possess, or use a production or utilization facility for industrial or commercial purposes." Any production or utilization facility which is also useful in the conduct of research and development activities is deemed to be used for industrial or commercial purposes if more than 50 percent of the annual cost of owning and operating the facility is devoted to (1) the production of materials, products, or energy for sale or commercial distribution or (2) to the sale of services other than research and development, education, or training. The standard review plan for LWR applications is found in NUREG-0800, Standard Review Plan for the Review of Safety Analysis Reports for Nuclear Power Plants: LWR Edition. Advanced reactor reviews (small modular reactors, non-LWRs, and microreactors) will be based on NUREG 0800 and the regulatory bases found in 10 CFR 50, Domestic Licensing of Production and Utilization Facilities, and 10 CFR 52, Licenses, Certifications, and Approvals for Nuclear Power Plants.

There are numerous licensing challenges for any level of autonomous control in microreactors regulated by the NRC. The requirements specified in 10 CFR 50.54, Conditions of Licenses, provide a basis for licensing issues for any reactor design that intends to implement a high degree of autonomous control. These issues include staffing, manipulation of controls, licensed operators, TSs, cybersecurity, and notifications. Each of these issues is discussed in this subsection. A brief summary of the possible NRC licensing processes is also included.

\footnotetext{
${ }^{1}$ The Energy Reorganization Act of 1974 (P.L. 93-438), Sec. 202, established the NRC and provided this regulatory authority.
} 


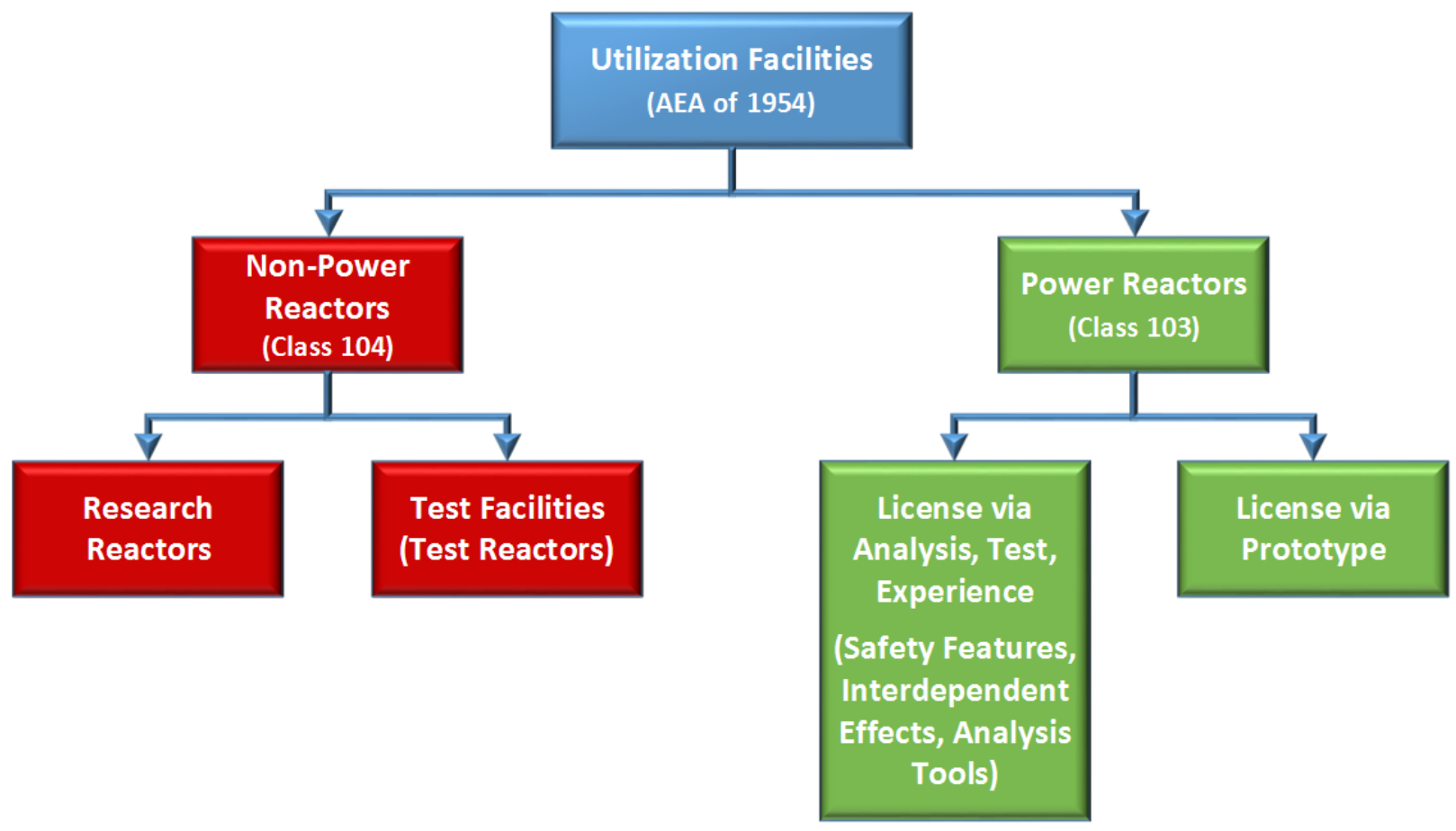

Figure 2. NRC Licensing Structure.

\subsubsection{Staffing}

Current regulations regarding licensed operator staffing are based on existing large LWRs that rely primarily on active safety systems and operator actions to address plant transients and design basis accidents. 10 CFR 50.54(k) and (m) specify the following:

(k) An operator or senior operator licensed pursuant to [10 CFR 55] of this chapter shall be present at the controls at all times during the operation of the facility.

(m)(1) A senior operator licensed pursuant to [10 CFR 55] shall be present at the facility or readily available on call at all times during its operation, and shall be present at the facility during initial start-up and approach to power, recovery from an unplanned or unscheduled shut-down or significant reduction in power, and refueling, or as otherwise prescribed in the facility license.

(m)(2)(ii) Each licensee shall have at its site a person holding a senior operator license for all fueled units at the site who is assigned responsibility for overall plant operation at all times there is fuel in any unit.

(m)(2) (iii) When a nuclear power unit is in an operational mode other than cold shutdown or refueling, as defined by the unit's technical specifications, each licensee shall have a person holding a senior operator license for the nuclear power unit in the control room at all times. In addition to this senior operator, for each fueled nuclear power unit, a licensed operator or senior operator shall be present at the controls at all times. 
For a single microreactor, 10 CFR 50.54(m)(2)(i) specifies the minimum requirements for on-site staffing by licensed operators and senior operators. This is shown in Table 1.

Table 1. Minimum Requirements Per Shift for On-Site Staffing of Nuclear Power Units by Operators and Senior Operators Licensed Under 10 CFR 55

\begin{tabular}{|l|l|c|}
\hline \multicolumn{1}{|c|}{$\begin{array}{c}\text { Number of nuclear power } \\
\text { units operating }\end{array}$} & \multicolumn{1}{|c|}{ Position } & One unit \\
\hline \multirow{2}{*}{ None } & Senior operator & 1 \\
\cline { 2 - 3 } & Operator & 1 \\
\hline \multirow{2}{*}{ One } & Senior operator & 2 \\
\cline { 2 - 3 } & Operator & 2 \\
\hline
\end{tabular}

The requirements of 10 CFR 50.54(m) would tend to prohibit reducing the operating staff based on a reactor design with a high level of autonomous control. However, the NuScale small modular reactor (SMR) design intends to seek an exemption from this requirement based on its passive safety systems, simplicity of operation, automation, reduced licensed operator workload, limited important human actions, and ample time to complete operator actions. These factors indicate different licensed operator staffing levels than that anticipated in 10 CFR 50.54(m) [12]. These attributes should also be associated with a reactor design with a high level of autonomous control.

NRC staff notified NuScale that they use the guidance in NUREG-0711 [13], "Human Factors Engineering Program Review Model," to verify that an applicant's human factors engineering program and its products reflect state-of-the-art human factors principles. The NRC staff has advised NuScale that if the control room staffing does not meet the requirements in 10 CFR 50.54(m), then NUREG-0711, Section 6.4, "Review Criteria," Criterion 2, then the staff are instructed to use the guidance in NUREG1791 [14], "Guidance for Assessing Exemption Requests from the Nuclear Power Plant Licensed Operator Staffing Requirements Specified in 10 CFR 50.54(m)," to determine whether the staffing proposal provides adequate assurance that public health and safety will be maintained at a level comparable to compliance with 10 CFR 50.54(m) [15].

NuScale commented that NRC Commission paper SECY-11-0098 [16] provides the NRC staff's proposed approach to resolving the issue of the appropriate number of on-site licensed operators for multimodule nuclear power plants, as well as potential requests for exemptions from the on-site operating staffing requirements in 10 CFR 50.54(m). SECY-11-0098 proposes a two-step approach where applicants can request exemptions to the current 10 CFR 50.54(m) operator staffing requirements in the near term. Once experience is gained, the staff would initiate a longer term solution to revise the regulations to specify the control room staffing requirements appropriate for SMRs [17]. Therefore, NuScale intends to seek a staffing exemption as part of the design certification and also will work to obtain a regulatory approach for their design in the longer term. This experience could provide more highly autonomous microreactor designers with a blueprint for a similar reduced staffing approach.

It should be noted that NuScale intends to reduce the number of operation staff onsite, but NuScale does not intend to eliminate the staff entirely, as a highly autonomous microreactor designer might prefer. Current nuclear plants require skilled, highly trained staff onsite. These staff members include certified operators, maintenance personnel, engineers, and management. The current staffing level for a 1,000 MWe plant is about 1,000, which is essentially one person per MWe [18].

In addition to the operational staff, there is a large, highly trained armed security force that is continuously present. Access to a nuclear power plant is generally restricted and requires prenotification and escorts for nonreactor employees. The security staffing level is generally about 75 people for operating nuclear plants [18]. In a DoD application, the military security force could fill this role. 
In addition to the staffing requirements identified in 10 CFR 50.54, 10 CFR 50.47 establishes requirements for nuclear power plant emergency response plans. Specifically, 10 CFR 50.47(b)(2) stipulates the standards for on-shift licensee responsibilities. The requirement is that adequate staffing be provided, but there is no regulatory requirement specified as to the number of licensed operators required to provide for on-shift accident response. NUREG-0654 [19-22] provides evaluation criteria for determining what constitutes adequate staffing, as well as guidance on the staffing levels that the NRC has determined to be acceptable. Specifically, Table B-1 of NUREG-0654, which addresses the minimum staffing requirements for NRC licensees for nuclear power plant emergencies, recommends 10 staff members onsite, 11 additional staff members available within 30 minutes, and 15 additional staff members available within 60 minutes. These totals do not include staffing for site access control and personnel accountability, which includes security, firefighting communications, and personnel accountability. Staffing levels for these personnel are determined according to the security plan.

Staffing at a microreactor with a colocated facility may require smaller staffing levels and fewer security forces. However, all staff within the exclusion boundary will be required to be trained and must have passed background checks. Access to the plant site would be restricted for those not cleared for access, and generally, such individuals will need to be escorted while on site.

\subsubsection{Manipulation of Controls}

The reactor protection system may automatically shut down the reactor if an unsafe condition or direction is sensed. However, licensed operators must be fully aware of any other manipulation of reactor controls, including any apparatus and mechanism other than controls that may affect the reactor's reactivity or power level as discussed in 10 CFR 50.54. This requirement will impact any consideration of highly autonomous reactor operation. The regulations are very specific regarding manipulation of the controls that affect the reactivity or power level of the reactor. 10 CFR 50.54(i) and (j) specify that:

(i) Except as provided in [10 CFR 55.13], the licensee may not permit the manipulation of the controls of any facility by anyone who is not a licensed operator or senior operator as provided in [10 CFR 55].

(j) Apparatus and mechanisms other than controls, the operation of which may affect the reactivity or power level of a reactor shall be manipulated only with the knowledge and consent of an operator or senior operator licensed pursuant to [10 CFR 55] present at the controls.

Highly autonomous reactor designs will have to prove significant safety margins regarding reactivity insertions and power level changes. The requirement for prior licensed operator knowledge and consent of reactivity and power level changes will need to be explored in detail regarding a highly autonomous reactor design.

The close coupling of a nuclear reactor and a process facility raises concerns involving interface requirements and regulatory jurisdiction issues. Collocated industries taking heat energy from the reactor cannot change the steam demand directly to suit the needs of their process streams. This implies apparatus and mechanisms other than reactor controls that may affect reactivity or power level. Only the licensed operator at the nuclear plant can initiate an action that will change the power level of the reactor via reactor controls or provide prior consent if remote apparatus or mechanisms are likely to change the reactor's power level. This coupling will require a level of integration and communication between the nuclear energy supplier and the end user that does not typically exist in industry. This approach will also add a layer of complexity to the nuclear operator and collocated industry, especially if highly autonomous 
controls are being integrated into nuclear and industry processes. The effects of the reactor on the commercial product of the industrial facility during normal operation must also be considered.

\subsubsection{Licensed Operators}

From the time a reactor commences operation until the plant is decommissioned, regulations require that licensed operators be continuously present at the controls. Additionally, the licensed operator at the reactor controls should be under constant supervision as specified in 10 CFR 50.54(k) and (1):

(k) An operator or senior operator licensed pursuant to [10 CFR 55] of this chapter shall be present at the controls at all times during the operation of the facility.

(l) The licensee shall designate individuals to be responsible for directing the licensed activities of licensed operators. These individuals shall be licensed as senior operators pursuant to [10 CFR 55] of this chapter.

Licensed operators continuously turn plant responsibility over, including official designation of who is responsible for the controls at any moment. These transitions extend to bathroom and food breaks. Each licensed operator is granted a license by the NRC as noted in 10 CFR 55.3, License Requirements:

A person must be authorized by a license issued by the Commission to perform the function of an operator or a senior operator as defined in this part.

An operator is defined in 10 CFR 55.4 as "any individual licensed under this part to manipulate a control of a facility." Likewise, a senior operator is defined as "any individual licensed under this part to manipulate the controls of a facility and to direct the licensed activities of licensed operators." Exemptions are provided in 10 CFR 55 for individuals in training to manipulate the controls under the direction of a licensed operator or senior operator. The NRC will grant a license (10 CFR 55 Subpart F) to individuals who meet medical requirements (10 CFR 55 Subpart C) and pass written and operating tests (10 CFR 55 Subpart E). Licenses are conditional as specified in 10 CFR 55.53, including:

(b) The license is limited to the facility for which it is issued.

(c) The license is limited to those controls of the facility specified in the license.

Each license expires after 6 years and must be renewed by continuing to meet medical requirements and pass written and operating tests.

It is conceivable that the reactor control room may not be colocated with the nuclear power plant due to implementation of highly autonomous controls in the design and remote siting. However, licensed operators dedicated to that facility are required under current regulations.

\subsubsection{Technical Specifications}

Various requirements in 10 CFR 50.54 reference operating in accordance with TSs. Highly autonomous reactor designs must, therefore, consider TSs as discussed in 10 CFR 50.36, Technical Specifications. As noted in the regulation, the "TS will be derived from the analyses and evaluation included in the safety analysis report," and highly autonomous reactor designs will need to consider design safety limits, limiting safety settings, and limiting control settings based on these analyses. The limits and associated settings are defined in 10 CFR 50.36(c): 
Safety limits for nuclear reactors are limits upon important process variables that are found to be necessary to reasonably protect the integrity of certain of the physical barriers that guard against the uncontrolled release of radioactivity. If any safety limit is exceeded, the reactor must be shut down.

Limiting safety system settings for nuclear reactors are settings for automatic protective devices related to those variables having significant safety functions. Where a limiting safety system setting is specified for a variable on which a safety limit has been placed, the setting must be so chosen that automatic protective action will correct the abnormal situation before a safety limit is exceeded.

Limiting conditions for operation [LCO] are the lowest functional capability or performance levels of equipment required for safe operation of the facility. When a limiting condition for operation of a nuclear reactor is not met, the licensee shall shut down the reactor or follow any remedial action permitted by the technical specifications until the condition can be met.

10 CFR 50.36 requires that a TS LCO be established if any of the following criteria are met:

1. Installed instrumentation that is used to detect, and indicate in the control room, a significant abnormal degradation of the reactor coolant pressure boundary.

2. A process variable, design feature, or operating restriction that is an initial condition of a design basis accident or transient analysis that either assumes the failure of or presents a challenge to the integrity of a fission product barrier.

3. A structure, system, or component that is part of the primary success path and which functions or actuates to mitigate a design basis accident or transient that either assumes the failure of or presents a challenge to the integrity of a fission product barrier.

4. A structure, system, or component which operating experience or probabilistic risk assessment has shown to be significant to public health and safety.

Surveillance requirements relate to "testing, calibration, or inspection to assure that the necessary quality of systems and components is maintained, that facility operation will be within safety limits, and that the limiting conditions for operation will be met." Likewise, administrative controls provide the necessary "provisions relating to organization and management, procedures, recordkeeping, review and audit, and reporting necessary to assure operation of the facility in a safe manner." Therefore, a highly autonomous reactor design must operate the reactor within TS guidelines, provide for appropriate equipment surveillance, and provide acceptable recordkeeping and other administrative controls. Onsite licensed and unlicensed operators currently provide for equipment surveillance and the associated recordkeeping.

\subsubsection{Cybersecurity}

Security, including cybersecurity, is a required condition of any license as directed in 10 CFR $50.54(\mathrm{p})(1)$ :

(p)(1) The licensee shall prepare and maintain safeguards contingency plan procedures in accordance with appendix C of [10 CFR 73] for affecting the actions and decisions contained in the Responsibility Matrix of the safeguards contingency plan. The licensee may not make a change which would decrease the effectiveness of a physical security plan, or guard training and qualification plan, or cyber security plan prepared under 10 CFR 50.34(c) or 10 CFR 52.79(a), or 10 CFR 73 of this chapter. ... 
Both CFR 50.34(c) and 10 CFR 52.79(a) specify the content of license applications under varying licensing paths. Both specify that a cybersecurity plan is required as set forth in 10 CFR 73.54, Protection of Digital Computer and Communication Systems and Networks:

(a) Each licensee subject to the requirements of this section shall provide high assurance that digital computer and communication systems and networks are adequately protected against cyber-attacks. ...

Within 10 CFR 73.54, the licensee is directed to protect digital computer and communication systems and networks associated with:

- Safety-related and important-to-safety functions;

- Security functions;

- Emergency preparedness functions, including offsite communications; and

- Support systems and equipment which, if compromised, would adversely impact safety, security, or emergency preparedness functions.

Specifically, the cybersecurity program must be designed to:

- Implement security controls to protect the assets identified [above] from cyber-attacks;

- Apply and maintain defense-in-depth protective strategies to ensure the capability to detect, respond to, and recover from cyber-attacks;

- Mitigate the adverse effects of cyber-attacks; and

- Ensure that the functions of protected assets are not adversely impacted due to cyber-attacks.

Highly autonomous reactor designs will interface directly with safety-related and important-to-safety systems and functions. Therefore, cybersecurity will be an important consideration for any highly autonomous reactor design to demonstrate adequate protection of the health and safety of the public and the environment. Providing appropriate cybersecurity will be complicated if the design implements an offsite control room to support a remotely sited reactor.

\subsubsection{Notifications}

The condition of any license under 10 CFR 50.54(z) requires that:

Each licensee with a utilization facility licensed pursuant to sections 103 or 104b. of the [AEA] shall immediately notify the NRC Operations Center of the occurrence of any event specified in [10 CFR 50.72].

As noted, the staff notification requirements for operating reactors are provided in 10 CFR 72, Immediate Notification Requirements for Operating Nuclear Power Reactors. 10 CFR 72(a)(3) specifically requires that:

The licensee shall notify the NRC immediately after notification of the appropriate State or local agencies and not later than one hour after the time the licensee declares one of the Emergency Classes [as specified in the licensee's approved Emergency Plan].

In addition to notification of the declaration of an emergency class, notification of many other events must be made in a timely manner. This includes: 
- The initiation of any nuclear plant shutdown required by the plant's TS

- Any event that results or should have resulted in emergency core cooling system discharge into the reactor coolant system

- Any event or condition that results in actuation of the reactor protection system when the reactor is critical

- Any event or situation, related to the health and safety of the public or onsite personnel, or protection of the environment, for which a news release is planned or notification to other government agencies has been or will be made

- The condition of the nuclear power plant, including its principal safety barriers, being seriously degraded

- The nuclear power plant being in an unanalyzed condition that significantly degrades plant safety

- Any event or condition that at the time of discovery could have prevented the fulfillment of the safety function of structures or systems that are needed to:

- Shut down the reactor and maintain it in a safe shutdown condition;

- Remove residual heat;

- Control the release of radioactive material; or

$\circ$ Mitigate the consequences of an accident.

Therefore, a highly autonomous reactor must be designed so that operating staff are apprised of any notifications that must be made in a timely manner.

\subsubsection{NRC License Process}

NRC requires that an application - including the applicant's safety analysis and environmental reportsbe submitted for verification of adequacy prior to its formal review. Only when the staff is satisfied as to its quality and completeness is the application placed on the docket, and the agency publishes a notice of receipt in the Federal Register. NEI recommends pre-application engagement as part of the application process [23].

\subsubsection{Construction Permit and Operating License (10 CFR 50)}

Obtaining an operating license (OL) under 10 CFR 50 is a two-step process that consists of an applicant first applying for a construction permit (CP) and then an OL as construction is completed. After the NRC reviews and is satisfied with the safety of the preliminary plant design and the suitability of the prospective site, the agency issues a $\mathrm{CP}$ that allows an applicant (e.g., utility, DoD, DOE) to begin building a plant. A CP constitutes an authorization to the applicant to proceed with construction, but it does not constitute Commission approval of the safety of any design feature or specification. The permitting process for a $\mathrm{CP}$ is shown in Figure 3. 


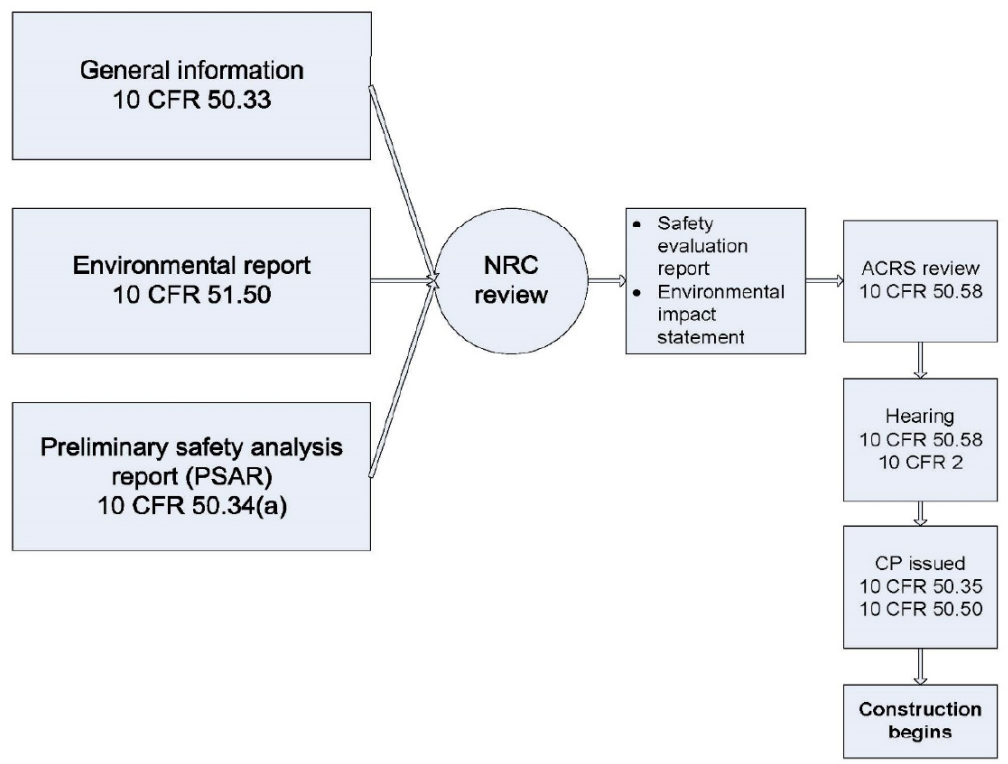

Figure 3. 10 CFR 50 construction permit process [24].

Sometime during construction, an application for an OL is submitted. Once it has been determined that an application for a license meets the standards and requirements of the AEA and NRC regulations and that any notifications to other agencies or bodies have been duly made, the Commission will issue a license (10 CFR 50.50). The issuance of an OL (10 CFR 50.57) indicates that the construction of the facility has been substantially completed, the facility will operate in conformity with the application as amended, and there is reasonable assurance that the activities authorized by the OL can be conducted without endangering the health and safety of the public. The permitting process for an OL is shown in Figure 4.

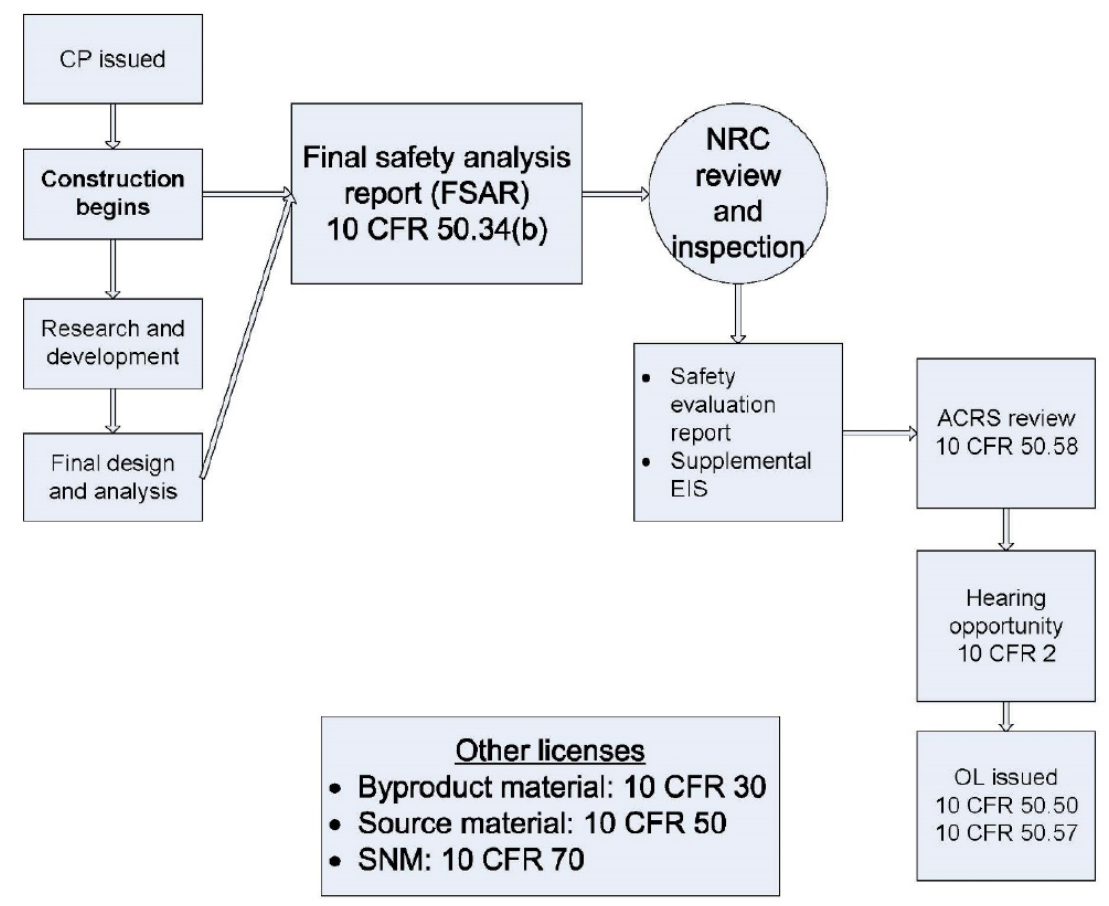

Figure 4. 10 CFR 50 operating license process [24]. 


\subsubsection{Combined License (10 CFR 52)}

In 1989, the NRC established new alternatives for nuclear plant licensing under 10 CFR 52, which describes

- $\quad$ an early site permit (10 CFR 52.17),

- a standard plant design certification (10 CFR 52.47), and

- a combined license (COL) (10 CFR 52.79).

A COL authorizes construction and conditional operation of a nuclear power plant. The application for a COL must contain essentially the same information required in an application for an OL issued under 10 CFR 50. The application must also describe the inspections, tests, analyses, and acceptance criteria (ITAAC) that are necessary to ensure that the plant has been properly constructed and will operate safely. The permitting process for a COL is shown in Figure 5.

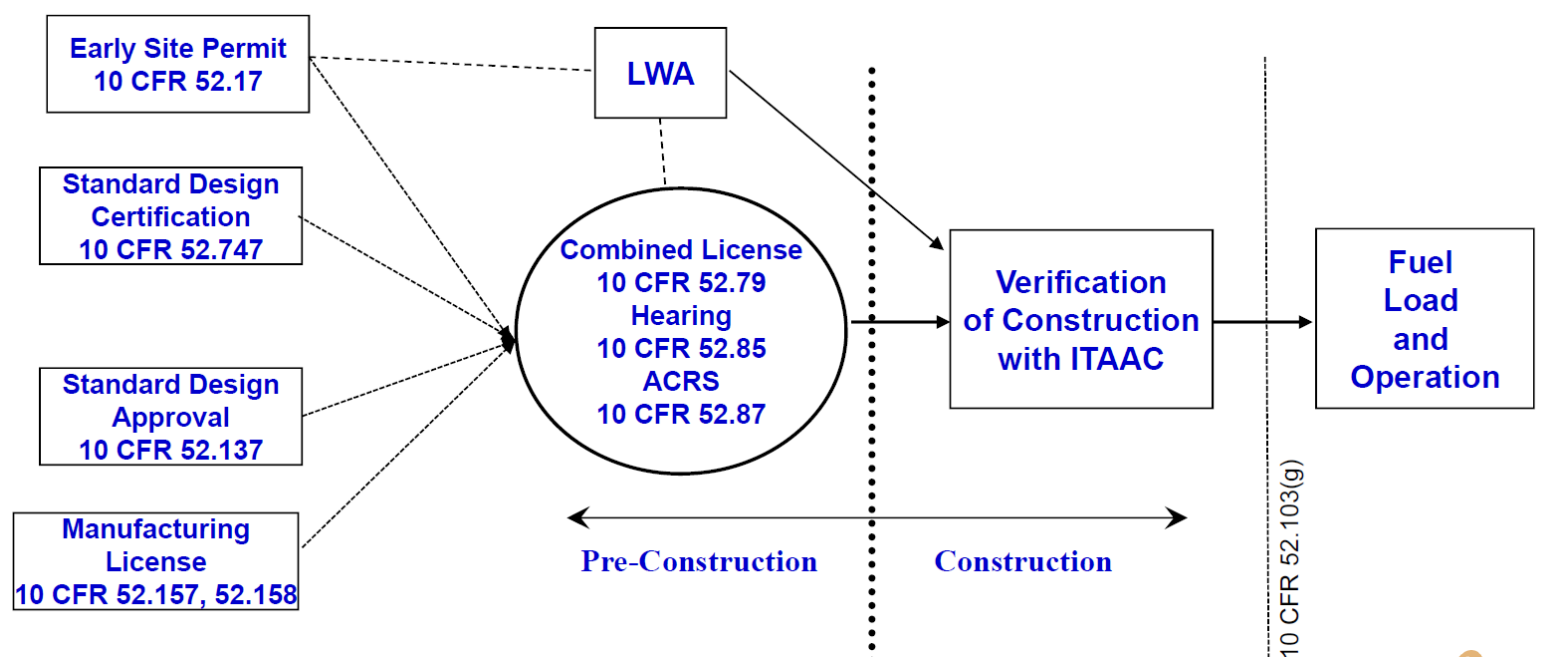

Figure 5. 10 CFR 52 licensing process [24].

\subsection{DEPARTMENT OF ENERGY AS THE AUTHORIZATION AUTHORITY}

In certain cases, reactors located on DOE sites can be authorized and regulated by DOE without NRC licensing. However, any reactor on a DOE site can also be licensed and regulated by the NRC. The caveat is that any reactors located on DOE sites that are operated for the purpose of demonstrating the suitability of a commercial application or producing energy must be licensed by the NRC. ${ }^{1}$ Alternatively, DOE test and research reactors can be authorized under 10 CFR 830, Nuclear Safety Management. Under the direction of 10 CFR 830, the safety analysis is prepared using NRC Regulatory Guide 1.70 [25], Standard Format and Content of Safety Analysis Reports for Nuclear Power Plants (LWR Edition), or a successor document. Regulatory Guide (RG) 1.70 was last revised in November 1978. The most recent NRC regulatory review of RG 1.70 took place in September 2014, when it was noted that since the development of RG 1.70, there have been several updates to RGs, as well as additional sections of NUREG 0800 in support of new reactor licensing. As such, RG 1.70 is no longer being exclusively used by applicants for licensing new reactors. RG 1.206 [26], Combined License Applications for Nuclear Power Plants (LWR Edition), was developed to provide guidance to applicants who planned to use the 10 CFR Part 52 process to reference an early site permit, a design certification, both, or neither, in a COL application. RG 1.206 was based on the existing guidance provided in RG 1.70. 
Barring a change in the statute, only research or test reactors (nonpower reactors) can be authorized using a DOE review process. Use of RG 1.70 or RG 1.206 to prepare a nonpower reactor application leads to a DOE review process like that found in NUREG-0800. This would lead to a review of a highly autonomous nonpower reactor design with issues like those described in Section 3.1, with NRC as the regulatory authority.

\subsection{DEPARTMENT OF DEFENSE AS THE AUTHORIZATION AUTHORITY}

Power reactors on US DoD facilities would typically be licensed and regulated by the NRC. However, the AEA — as amended through Public Law 115-246 enacted September 28, 2018 and United States Code (USC), Title 42, The Public Health and Welfare, Section 2121 (42 USC 2121) - provides that:

\section{(b)(2) The President from time to time may authorize the Department of Defense to manufacture, produce, or acquire any atomic weapon or utilization facility for military purposes: Provided, however, that such authorization shall not extend to the production of special nuclear material other than that incidental to the operation of such utilization facilities.}

This provides a legal basis to allow DoD to operate power reactors (utilization facilities) as directed by the President.

Likewise, an exemption could be applied by Congress such as the Naval Nuclear Propulsion Program exemption noted in 10 CFR 830 per Public Law 106-65. Presidential Executive Order 12344, 42 USC 7158, Public Law 98-525 and 50 USC 2406, Public Law 106-65 set forth the total responsibility of Naval Reactors for all aspects of the Navy's nuclear propulsion, including research, design, construction, testing, operation, maintenance, and ultimate disposition of naval nuclear propulsion plants [27].

The Naval Reactor Program responsibility includes all related facilities, radiological controls, environmental safety, and health matters, as well as selection, training, and assignment of personnel. All this work is accomplished by a lean network of dedicated research laboratories, nuclear-capable shipyards, equipment contractors and suppliers, and training facilities which are centrally controlled by a small headquarters staff [27]. Naval Reactors seeks reviews of its reactor designs from NRC. Such an arrangement allows more autonomy to the Naval Reactor Program in reactor design and operation. However, the health and safety of the public and the environment remain a priority.

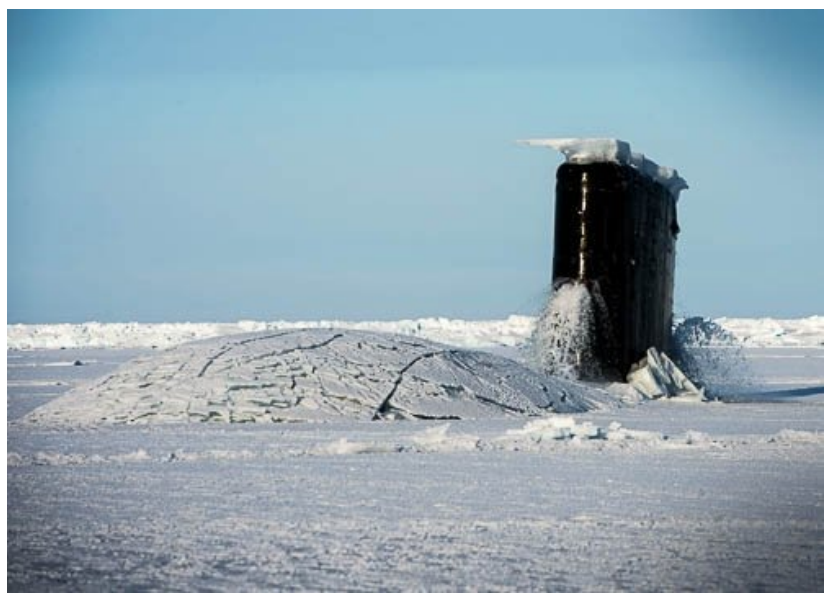

Figure 6. Navy submarines reflect remotely operating DoD reactors [27]. 
Under current statutes, US-based power microreactors employing highly autonomous controls will be licensed and regulated by the NRC. In this case, the discussion in Section 3.1 with NRC as the regulatory authority, will apply. Still, the Naval Reactors program offers an example of a successful DoD program to design, authorize, and regulate small power reactors. It is unlikely that $\mathrm{DoD}$ would pursue a rule change to govern microreactor applications [10], but it remains a possibility.

In the case of a government-owned, government-operated power plant, it is permissible to sell excess electricity to the immediate local vicinity if equivalent services are not available under 10 USC 2686, Armed Forces, Utilities and Services.

\section{SUMMARY}

The primary path for the licensing and regulation of US-based highly autonomous microreactors lies with the NRC. This is because, by statute, DOE and DoD are not currently positioned to license power reactors, although DoD could be authorized by the President and Congress to do so through a program like the Naval Reactors program for nuclear propulsion.

Conditions for current NRC reactor licenses are specified in 10 CFR 50.54. These conditions provide a basis for evaluating potential licensing issues for any microreactor design that intends to implement a high degree of autonomous control. Some of the license conditions that may be problematic for highly autonomous reactors relate to staffing, manipulation of controls, licensed operators, TSs, cybersecurity, and notifications.

Current regulations regarding licensed operator staffing are based on existing large LWRs that rely primarily on active safety systems and operator actions to address plant transients and design basis accidents. 10 CFR 50.54(k) and (m) are very specific regarding control room staffing. The NuScale SMR design intends to support justification for an exemption from this requirement because the passive safety systems, simplicity of operation, automation, reduced licensed operator workload, limited important human actions, and ample time to complete operator actions indicate that licensed operator staffing levels would be different than what was anticipated in 10 CFR 50.54(m). These attributes should also be associated with a reactor design with a high level of autonomous control.

In addition to the staffing requirements identified in 10 CFR 50.54, 10 CFR 50.47 establishes requirements for nuclear power plant emergency response plans. 10 CFR 50.47(b)(2) requires that adequate staffing be provided, with no regulatory requirement specified as to the number of licensed operators required to provide for on-shift accident response. NUREG-0654 provides evaluation criteria for determining what constitutes adequate staffing and provides guidance on staffing levels that the NRC has determined to be acceptable. Staffing at a microreactor with a colocated facility may require smaller staffing levels and fewer security forces, but complete elimination will be more problematic.

Licensed operators must be fully aware of any manipulation of reactor controls, including apparatus and mechanisms other than controls that may affect the reactivity or power level of the reactor as discussed in 10 CFR 50.54(i) and (j). Operator knowledge and consent are key components of this regulation. Highly autonomous reactor designs must prove significant safety margins regarding reactivity insertions and power level changes.

From the time a reactor commences operation until the plant is decommissioned, regulations require that licensed operators be continuously present at the controls. Licensed operators continuously turn responsibility for the plant over, including the official designation of who is responsible for the controls at any moment. This extends to bathroom and food breaks. An operator is defined in 10 CFR 55.4 as "any 
individual licensed under this part to manipulate a control of a facility." Likewise, a senior operator is defined as "any individual licensed under this part to manipulate the controls of a facility and to direct the licensed activities of licensed operators." It is conceivable that the reactor control room may not be colocated with the nuclear power plant due to the implementation of highly autonomous controls in the design and remote siting. However, licensed operators dedicated to that facility are required under current regulations.

Various requirements in 10 CFR 50.54 reference operating in accordance with TSs. Therefore, highly autonomous reactor designs must consider TSs regarding design safety limits, limiting safety settings, and limiting control settings as discussed in 10 CFR 50.36. A highly autonomous reactor design must operate the reactor with TS guidelines, provide for appropriate equipment surveillance, and provide acceptable recordkeeping and other administrative controls. Onsite licensed and unlicensed operators currently provide for equipment surveillance and the associated recordkeeping.

Security, including cybersecurity, is a required condition of any license as directed in 10 CFR 50.54(p)(1) and expanded in 10 CFR 73.54. Each licensee must provide high assurance that digital computer and communication systems and networks are adequately protected against cyber-attacks. Highly autonomous reactor designs will interface directly with safety-related and important-to-safety systems and functions. Therefore, cybersecurity will be an important consideration for any highly autonomous reactor design to demonstrate adequate protection of the health and safety of the public and the environment. Providing appropriate cybersecurity will be complicated if the design implements an offsite control room to support a remotely sited reactor.

The condition of any license under 10 CFR 50.54(z) requires that a licensee immediately notify the NRC Operations Center of the occurrence of any event specified in 10 CFR 50.72. This would include declaration of an Emergency Class as specified in the licensee's approved Emergency Plan. Required notifications also include:

- Any event or situation, related to the health and safety of the public or onsite personnel, or protection of the environment, for which a news release is planned or notification to other government agencies has been or will be made

- The condition of the nuclear power plant, including its principal safety barriers, being seriously degraded

- The nuclear power plant being in an unanalyzed condition that significantly degrades plant safety

- Any event or condition that at the time of discovery could have prevented the fulfillment of the safety function of structures or systems that are needed to:

- Shut down the reactor and maintain it in a safe shutdown condition;

- Remove residual heat;

- Control the release of radioactive material; or

- Mitigate the consequences of an accident.

Therefore, a highly autonomous reactor must be designed so that (1) notifications are made automatically as required or (2) that operating staff are apprised of notifications that must be made in a timely manner.

Highly autonomous microreactors will likely need to demonstrate a high degree of passive safety and a small source term. Such attributes will allow a minimal emergency plan, which could lead to reduced onsite staffing and will potentially allow a remotely located control room. 


\section{REFERENCES}

1. The Role of Microgrids in Helping to Advance the Nation's Energy System, https://www.energy.gov/oe/activities/technology-development/grid-modernization-and-smartgrid/role-microgrids-helping, Accessed November 2, 2018.

2. R.T. Wood et al., Autonomous Control for Generation IV Nuclear Plants, Proceedings of the $14^{\text {th }}$ Pacific Basin Nuclear Conference, Honolulu, HI, March 2004, American Nuclear Society (2004), pp. 517-522.

3. R.T. Wood et al., An Autonomous Framework for Advanced Reactors, Nuclear Engineering and Technology, Volume 49, July 2017, pp. 896-904.

4. H. Basher and J. S. Neal, Autonomous Control of Nuclear Power Plants, ORNL/TM-2003/252, Oak Ridge National Laboratory, Oak Ridge, Tennessee, October 2003.

5. P. J. Antsaklis and K.M. Passino, An Introduction to Intelligent and Autonomous Control, Kluwer Academic Publishers, Boston, 1992.

6. K. J. Astrom, Toward Intelligent Control, IEEE Control System Magazine, April 1989.

7. T. R. Chaudhuri, L.G.C. Hamey, and R.D. Bell, From Conventional to Autonomous Intelligent Methods, IEEE Control System Magazine, October 1996.

8. K. M. Passino, Intelligent Control for Autonomous Systems, IEEE Spectrum, June 1995.

9. M. V. Ramana, The Forgotten History of Small Nuclear Reactors, IEEE Spectrum, April 27, 2015.

10. DoD Defense Science Board, Task Force on Energy Systems for Forward/Remote Operating Bases, Final Report, August 1, 2016.

11. M. Nichol, Roadmap for the Deployment of Micro-reactors for US Department of Defense Domestic Installations, NEI Technical Report, NEI New Reactor Deployment, October 4, 2018.

12. T. A. Bergman, NuScale Power, LLC Submittal of Response to NRC's letter, "NuScale Control Room Configuration and Staffing Levels, ” January 14, 2016, NuScale Power letter LO-0316-48185 to NRC Docket, April 8, 2016 (ML16099A270).

13. NUREG-0711, Rev. 3, Human Factors Engineering Program Review Model, Revision 3, November 2012 (ML12324A013).

14. NUREG-1791, Guidance for Assessing Exemption Requests from the Nuclear Power Plant Licensed Operator Staffing Requirements Specified in 10 CFR 50.54(m), July 2005 (ML052080125).

15. F. Akstulewicz, NuScale Control Room Configuration and Staffing Levels, NRC letter to NuScale Power, January 14, 2016 (ML15302A516).

16. SECY-11-0098, Operator Staffing for Small or Multi-Module Nuclear Power Plant Facilities, July 2011 (ML111870574).

17. T. A. Bergman, NuScale Power, LLC Submittal of "Human Factors Engineering Staffing and Qualifications Implementation Plan," (NRC Project No. 0769), NuScale Power letter LO-031622098 to NRC Docket, March 14, 2016 (ML16074A434).

18. S. R. Greene, G. F. Flanagan, and A. P. Borole, Integration of Biorefineries and Nuclear Cogeneration Power Plants - A Preliminary Analysis, ORNL/TM-2008/102 (ORNL/GNEP/LTR2008-047), March 9, 2009.

19. NUREG-0654, Rev. 1, Criteria for Preparation and Evaluation of Radiological Emergency Response Plans and Preparedness in Support of Nuclear Power Plants, November 1980 (ML040420012). 
20. NUREG-0654, Rev. 1, Supp. 1, Criteria for Preparation and Evaluation of Radiological Emergency Response Plans and Preparedness in Support of Nuclear Power Plants, Criteria for Utility Offsite Planning and Preparedness, September 1988 (ML083180169).

21. NUREG-0654, Rev. 1, Supp. 2, Criteria for Preparation and Evaluation of Radiological Emergency Response Plans and Preparedness in Support of Nuclear Power Plants, Criteria for Emergency Planning in an Early Site Permit Application, April 1996 (ML050130188).

22. NUREG-0654, Rev. 1, Supp. 3, Criteria for Preparation and Evaluation of Radiological Emergency Response Plans and Preparedness in Support of Nuclear Power Plants, Guidance for Protective Action Strategies, November 2011 (ML113010596).

23. K. Austgen, NEI Technical Report, Guidelines for Development of a Regulatory Engagement Plan, NEI 18-06, Rev 0, June 2018.

24. Joe Williams, Senior Project Manager, Office of New Reactors, Existing NRC Regulations, Policies, and Guidance for Licensing, September 1, 2015 (ML15245A744).

25. Regulatory Guide 1.70, Rev. 3, Standard Format and Content of Safety Analysis Reports for Nuclear Power Plants (LWR Edition), November 1978 (ML011340072).

26. Regulatory Guide 1.206, Combined License Applications for Nuclear Power Plants (LWR Edition), June 2007 (ML070630003).

27. National Nuclear Security Administration, Naval Reactors, Powering the Navy, https://www.energy.gov/nnsa/missions/powering-navy, accessed 11/14/2018. 